\title{
No conflict of interest?
}

\author{
Benjamin John Floyd Dean · Benjamin Michael Davies
}

Received: 22 May 2013/Accepted: 7 July 2013/Published online: 13 July 2013

(c) Springer-Verlag Berlin Heidelberg 2013

I read the studies by Albert et al. [1,2] with great interest. Of note both studies were published in 2013 and both clearly state 'no competing interests'. The MAST (Modic Antibiotic Spine Therapy) Medical ${ }^{\mathrm{TM}}$ (http://www.mastmedical.com) website demonstrates that three of the study's authors are members of the 'MAST Academy'. Of note MAST Medi$\mathrm{cal}^{\mathrm{TM}}$ accepts payments from both clinicians and patients for various services relating to the diagnosis and treatment of lower back pain. A simple search of the Companies House website (http://www.companieshouse.gov.uk/) reveals that the companies 'MAST MEDICAL EDUCATIONAL SERVICES LIMITED' and 'MAST MEDICAL CONCEPT LIMITED' were both incorporated in April 2010. It is also notable that both Hanne Albert and Claus Manniche have been named directors of these companies since May 2010. I find it hard to see how these important facts have not been declared by the authors as a conflict of interest in both studies.
Acknowledgments Jean Shanks Foundation, NIHR Oxford Biomedical Research Unit, Orthopaedic Research UK.

Conflict of interest None declared.

\section{References}

1. Albert $\mathrm{HB}$ et al (2013) Antibiotic treatment in patients with chronic low back pain and vertebral bone edema (Modic type 1 changes): a double-blind randomized clinical controlled trial of efficacy. Eur Spine J 22(4):697-707

2. Albert HB et al (2013) Does nuclear tissue infected with bacteria following disc herniations lead to Modic changes in the adjacent vertebrae? Eur Spine J 22(4):690-696
B. J. F. Dean $(\bowtie)$. B. M. Davies

Nuffield Department of Orthopaedics, Rheumatology and Musculoskeletal Sciences (NDORMS), Botnar Research Centre, Institute of Musculoskeletal Sciences, Nuffield Orthopaedic Centre, Windmill Road, Oxford OX3 7LD, UK

e-mail: bendean1979@gmail.com;

benjamin.dean@ndorms.ox.ac.uk

B. M. Davies

e-mail: benjmain.davies@ndorms.ox.ac.uk 